\title{
Yield performance of soybean cultivars with indeterminate growth habits in response to plant spatial arrangement
}

\author{
Desempenho produtivo de cultivares de soja de crescimento \\ indeterminado em resposta a arranjos espaciais de plantas
}

\author{
André Sampaio Ferreira ${ }^{1 *}$; Alvadi Antonio Balbinot Junior²; Flávia Werner"; \\ Claudemir Zucareli ${ }^{3}$
}

\begin{abstract}
Modifications in plant spatial arrangements, such as the use of narrow rows, twin rows, and crossed rows, may favor the development and productivity of soybeans due to the morphophysiological changes occurring in the plants. The aim of this research was to assess yield components, mortality rate, harvest index, and the yield, of two soybean cultivars, with indeterminate growth habits, in response to alternative plant spatial arrangements. The experiment was conducted in Londrina, Paraná State, Brazil, in the 2013/14 and 2014/15 growing seasons, with randomized complete block design, in a 4 $\times 3 \times 2$ factorial scheme, with three replications. The treatments were composed of four row spacings, at $0.2 \mathrm{~m}$ (narrow rows); $0.2 / 0.8 \mathrm{~m}$ (twin rows); $0.5 \mathrm{~m}$ (traditional); and $0.5 \mathrm{~m}$ (crossed rows); at three seeding rates $\left(150,300\right.$, and 450 thousand viable seeds ha $\left.{ }^{-1}\right)$ in two cultivars (BMX Potência RR and BRS 359 RR). In both growing seasons, there was a water deficit, and climatic conditions that would restrict soybean growth and development. The narrow rows, twin rows, and crossed rows did not favor yield performance compared to traditional spacing in either cultivar. The tested cultivars showed high phenotypic plasticity, allowing large changes in row spacing and seeding rate without major changes in the yield. The narrow rows, when associated with a high seeding rate, favored plant mortality. Grains per pod and harvest index were not influenced by the plant spatial arrangement.
\end{abstract}

Key words: Plant density. Row spacing. Narrow rows. Twin rows. Crossed rows.

\section{Resumo}

Modificações no arranjo espacial de plantas, como o uso de espaçamento reduzido, de fileiras duplas e semeadura cruzada podem favorecer o crescimento e o rendimento de grãos da soja em virtude das alterações morfofisiológicas ocorridas nas plantas. $\mathrm{O}$ objetivo do trabalho foi avaliar os componentes de rendimento, a taxa de mortalidade, o índice de colheita e o rendimento de grãos de duas cultivares de soja com tipo de crescimento indeterminado em resposta a arranjos espaciais de plantas alternativos. O experiment foi conduzido em Londrina-PR, nas safras 2013/14 e 2014/15, sob o delineamento experimental de blocos completes casualizados, em esquema fatorial 4 × 3 × 2, com 3 repetições. Os tratamentos foram constituídos de quatro espaçamentos entre fileiras, sendo $0,2 \mathrm{~m}$ (reduzido); 0,2/0,8 $\mathrm{m}$ (fileirasduplas); 0,5 m (cruzado) e $0,5 \mathrm{~m}$ (tradicional); três densidades de semeadura (150,300 e 450 mil sementes viáveis ha ${ }^{-1}$ ) e duas cultivares (BMX Potência RR e BRS 359 RR). Em ambas as

1 Discentes de Doutorado em Agronomia, UEL, Londrina, PR, Brasil. E-mail: andresampaioferreira@gmail.com; flawerner6@ gmail.com

2 Pesquisador Dr., Empresa Brasileira de Pesquisa Agropecuária, Embrapa Soja, Londrina, PR, Brasil. E-mail: alvadi.balbinot@ embrapa.br

3 Prof. Dr., Departamento de Agronomia, UEL, Londrina, PR, Brasil. E-mail: claudemircca@uel.br

* Author for correspondence 
safras houve deficit hídrico e condições climáticas restritivas ao crescimento e desenvolvimento da soja. Os arranjos em espaçamento reduzido, fileiras duplas e cruzado não favorecem o desempenho produtivo em relação ao espaçamento tradicional, para ambas as cultivares. As cultivares testadas apresentam alta plasticidade fenotípica, permitindo modificações no espaçamento e na densidade sem alterações expressivas no rendimento de grãos. $\mathrm{O}$ espaçamento reduzido, quando associado à alta densidade, aumenta a mortalidade de plantas. O número de grãos por vagem e o índice de colheita não são influenciados pelo arranjo espacial de plantas.

Palavras-chave: Densidade de plantas. Espaçamento entre fileiras. Espaçamento reduzido. Fileiras duplas. Semeadura cruzada.

\section{Introduction}

The soybean production system has been through some changes such as: increased cost of seeds due to biotechnology (BOARD; KAHLON, 2013), cultivars with increased productive potential (KOESTER et al., 2014), introduction of cultivars with indeterminate growth type, more compact structure (lower size and smaller leaflets), an early cycle (SOUZA et al., 2010), and consolidation of the Direct Planting System. Thus, it is necessary to update studies on plant arrangement, considering the currently employed technologies, because the new cultivars (early and with compact structure), may increase productivity due to reduced spacing and increased seeding rate.

In Brazil, the traditionally used row spacing is $0.45 \mathrm{~m}$ or $0.5 \mathrm{~m}$. However, narrow, twin and crossed rows are poorly explored options. One of the objectives of using narrow row spacing is to reduce the time the crop intercepts most of the solar radiation, optimizing canopy photosynthetic capacity (DE BRUIN; PEDERSEN, 2008). In addition, adjusting spacing may change root distribution in the area, water use efficiency, weed competition (ZHOU et al., 2015), morphology (COX; CHERNEY, 2011; WERNER et al., 2017), and soybean yield (HANNA et al., 2008). Some recent research showed that the effects of reduced spacing on yield vary according to cultivars and sowing time, with positive effects on indeterminate cultivars that are quite compact and sown at the beginning of the harvest (BALBINOT JUNIOR et al., 2016; PROCÓPIO et al., 2014).
Twin row sowing is a technique used in the United States, that consists of parallel line sowing, but alternating spacings between rows, one smaller and one larger. This arrangement increases the penetration of light and agrochemicals in the canopy, consequently increasing photosynthetic rate and longevity of the lower leaves, which could maximize grain yield (BRUNS, 2011a,b).

In crossed rows, half of the seeds are sown in one direction and the other half in the transverse direction, that is, the sowing rows are crossed (BALBINOT JUNIOR et al., 2015a). Recent studies indicate that the second sowing operation may negatively impact the establishment of stands due to soil rotation and additional compaction on the area already sown, which may have variable effects on grain yield (BALBINOT JUNIOR et al., 2015b; SILVA et al., 2015).

As for plant density, some studies showed low crop response to changes in the number of plants per area (FERREIRA et al., 2016; WERNER et al., 2016), due to the high phenotypic plasticity of soybeans. Balbinot Junior et al. (2016) showed that plant structure and branching potential are determinant factors for the response of cultivars to plant arrangement modifications.

Currently, the recommended seeding rate for each cultivar considers traditional spacing. However, seeding rate, spacing, and genotype, may interact, influencing soybean productive performance.

The objective of this study was to evaluate yield components, mortality rate, harvest index, and yield of two soybean cultivars with indeterminate 
growth types, in response to alternative plant spatial arrangements.

\section{Material and Methods}

The experiment was conducted in LondrinaPR (2319'21"S, 5120'46”'W, altitude $620 \mathrm{~m})$ in the 2013/14 and 2014/15 growing seasons. Regional climate is classified as humid subtropical (Cfa) according to the Köppen classification. The Thornthwaite and Mather sequential climatic water balance (SCWB) is presented in figures $1 \mathrm{a}$ and $1 \mathrm{~b}$ for the 2013/14 and 2014/15 seasons, respectively. The meteorological data were obtained at the agrometeorological station of Embrapa Soybean, located at about $600 \mathrm{~m}$ from the experiment site. To calculate SCWB, reference evapotranspiration (ETo) was calculated during the course of the experiment using the Penman-Monteith equation and transformed into soybean evapotranspiration $(\mathrm{ETc}=\mathrm{ETo} \times \mathrm{Kc})$, according to the crop coefficient (Kc) recommended by FAO (ALLEN et al., 1998). The available soil water capacity used to calculate SCWB was $75 \mathrm{~mm}$.

Figure 1. Thornthwaite and Mather sequential climatic water balance $(\mathrm{mm})$ in a ten-day period during the experiments. Londrina-PR, 2013/14 (A) and 2014/15 (B) growing seasons.
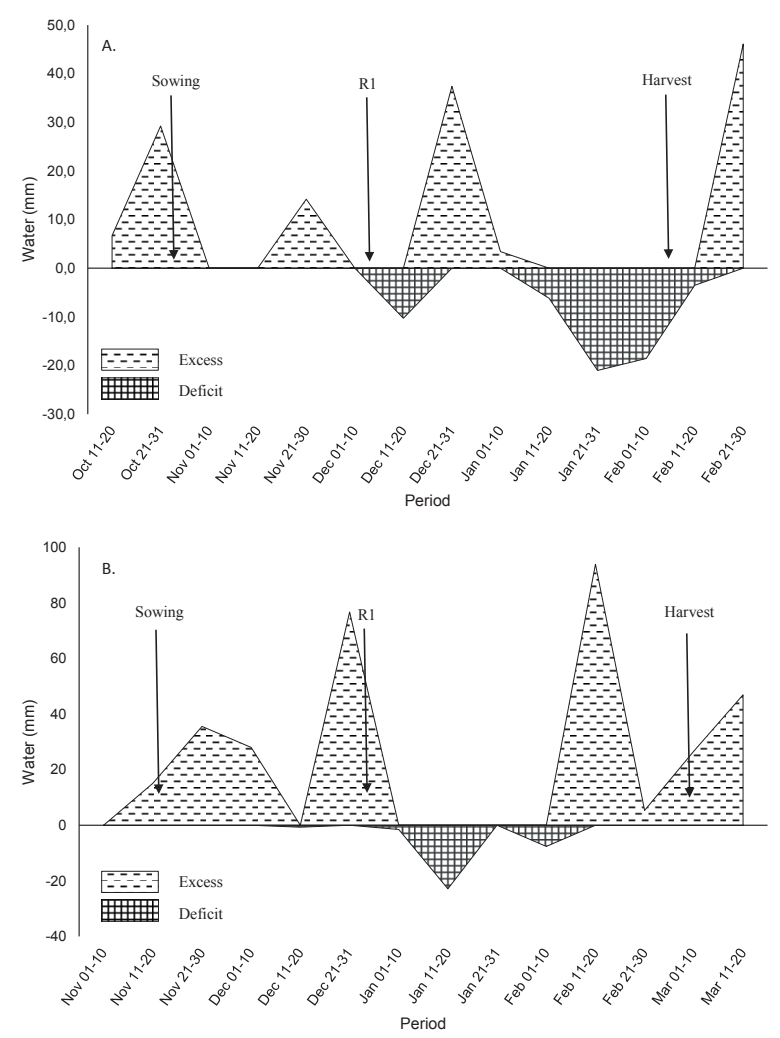

The soil of the experimental area is classified as Dystroferric Red Latosol and has been cultivated in the Direct Planting System for 15 years. The chemical attributes of the soil in the 0 to $20 \mathrm{~cm}$ layer at the time of the first crop implantation were:
$21.4 \mathrm{~g} \mathrm{dm}^{-3}$ organic matter; $\mathrm{pH} 4.9$ in $\mathrm{CaCl}_{2} ; 8.6 \mathrm{mg}$ $\mathrm{dm}^{-3} \mathrm{P}$ (Mehlich 1); $0.55 \mathrm{cmol}_{\mathrm{c}} \mathrm{dm}^{-3}$ exchangeable $\mathrm{K} ; 3.7 \mathrm{cmol}_{\mathrm{c}} \mathrm{dm}^{-3}$ exchangeable $\mathrm{Ca} ; 1.4 \mathrm{cmol}_{\mathrm{c}} \mathrm{dm}^{-3}$ exchangeable $\mathrm{Mg}$. 
The study used the randomized complete block experimental design with a $4 \times 3 \times 2$ factorial scheme, totaling 24 treatments, with three replications. The treatments were composed of four spacings between rows, $0.2 \mathrm{~m}$ (narrow), $0.2 / 0.8 \mathrm{~m}$ (twin), 0.5 $\mathrm{m}$ (traditional), and $0.5 \mathrm{~m}$ (crossed); three seeding rates $\left(150,300\right.$, and 450 thousand viable seeds ha $\left.{ }^{-1}\right)$; and two soybean cultivars (BMX Potência RR and BRS $359 \mathrm{RR}$ ). The plots were $10 \mathrm{~m}$ long and $5 \mathrm{~m}$ wide.

The BMX Potência RR and BRS 359 RR cultivars have an indeterminate growth type, and relative maturity groups of 6.7 and 6.0, respectively. The recommended seeding rate for the region is 265 to 310 thousand plants $\mathrm{ha}^{-1}$ for the BMX Potência $\mathrm{RR}$, and 220 to 265 thousand plants $\mathrm{ha}^{-1}$ for the BRS 359 RR. Sowing was carried out on October 23, 2013 and November 11, 2014, using an Imasa seeder model MPS 1800 for sowing narrow row $(0.2$ $\mathrm{m})$ and twin row $(0.2 / 0.8 \mathrm{~m})$ plots, and a Semeato seeder model SHM 11/13 for traditional row $(0.5 \mathrm{~m})$ and crossed row $(0.5 \mathrm{~m})$ plots.

Seeds were treated with Vitavax-Thiram 200 $\mathrm{SC}^{\text {TM }}$ (Carboxin + Thiram $-3 \mathrm{~mL} \mathrm{~kg}^{-1}$ seeds) and Gelfix $5^{\text {TM }}$ liquid inoculant $\left(5 \times 10^{9}\right.$ colony-forming units $\mathrm{mL}^{-1} ; 2 \mathrm{~mL} \mathrm{~kg}^{-1}$ seeds) on the sowing day. In the 2014/15 crop, the area was irrigated three days before sowing using a $30 \mathrm{~mm}$ blade, due to drought in October (Figure 1b). Base fertilization consisted of $125 \mathrm{~kg} \mathrm{ha}^{-1}$ triple superphosphate $\left(41 \%\right.$ of $\left.\mathrm{P}_{2} \mathrm{O}_{5}\right)$, and $250 \mathrm{~kg} \mathrm{ha}^{-1}$ potassium chloride $\left(60 \%\right.$ of $\left.\mathrm{K}_{2} \mathrm{O}\right)$, distributed through hauling ten days before sowing. Weed, pest, and disease management were the same for all treatments and followed the technical recommendations for the crop.

The initial plant density was evaluated in $3 \mathrm{~m}^{2}$ of useful area at the V3 development stage in both crops. In the 2014/15 season, the final plant density $\mathrm{ha}^{-1}$ at R7 stage was also evaluated by counting $3 \mathrm{~m}^{2}$ at the same position where the initial plant density was evaluated, thus obtaining the mortality rate percentage.
At the time of harvest, 20 plants per plot were collected to evaluate the number of pods per plant, number of grains per pod, and the mass of one thousand grains. The quantification of the mass of one thousand grains included eight subsamples of one hundred grains per plot. In the 2014/15 season, the apparent harvest index (AHI) was also evaluated using a sample of 20 plants. The AHI does not consider the mass of senesced leaves and was estimated by the following equation: dry mass of grains/(dry mass of grains + dry mass of straw) (HAY, 1995). The useful area harvested was $24 \mathrm{~m}$ 2 ( $8 \mathrm{~m}$ long and $3 \mathrm{~m}$ wide). A combined automated harvester was used for the harvest. Grain yield was standardized at $130 \mathrm{~g} \mathrm{~kg}^{-1}$ moisture and expressed in $\mathrm{kg} \mathrm{ha}^{-1}$.

The Shapiro-Wilk test was used to verify that the data had normal distribution, and the Cochran test was used to verify homoscedasticity of the treatment variances. After verifying these assumptions, the data was submitted to analysis of variance and comparison of means by the Tukey test, at 5\% significance. Plant mortality rate was expressed in percentage and transformed into $\sqrt{\mathrm{x}}$.

\section{Results and Discussion}

The SCWB presented in Figure 1a shows that in the 2013/14 growing season there was a severe water deficit during the months of January and February, the grain filling period, which resulted in low grain mass and yield (Table 1). In the second harvest, water deficit was less intense than in the previous season and happened during the first 20 days of January, when the development of pods began. However, at the end of January and during February, water was replenished in the soil, indicating a better condition for grain filling in the second harvest.

It is clear that the environmental conditions during the experiments restricted the production potential of the evaluated cultivars, which can influence the cultivar response to the tested 
arrangements. According to Corassa et al. (2018), restrictive environments influence the response of soybeans to plant spatial arrangement changes, due to the lower compensatory ability of the crop challenged with scarce water and nutrients. However, water deficit periods associated with high temperatures are common in January and February in most soybean-producing regions in Brazil.

Table 1. Number of pods per plant (NPP), number of grains per pod (NGP), mass of one thousand grains (g) (M1000), and grain yield $\left(\mathrm{kg} \mathrm{ha}^{-1}\right)$ (YIELD), of soybean cultivars in response to different plant spatial arrangements. LondrinaPR, 2013/14 season.

\begin{tabular}{|c|c|c|c|c|}
\hline Variation factor & NPP & NGP & M1000 & YIELD \\
\hline \multicolumn{5}{|l|}{ Cultivar (C) } \\
\hline BMX Potência RR & 39.2 & $2.33 \mathrm{~A}$ & 88.39 & 1.613 \\
\hline BRS 359 RR & 42.24 & $2.14 \mathrm{~B}$ & 91.40 & 1.751 \\
\hline \multicolumn{5}{|l|}{ Spacing $(S)^{1}$} \\
\hline 0.2 & $46.24 \mathrm{~A}$ & 2.34 & 85.1 & 1.640 \\
\hline $0.2 / 0.8$ & $45.38 \mathrm{AB}$ & 2.22 & 91.64 & 1.256 \\
\hline 0.5 & $3764 \mathrm{BC}$ & 2.17 & 92.67 & 1.962 \\
\hline 0.5 crossed & $34.88 \mathrm{C}$ & 2.23 & 90.19 & 1.869 \\
\hline \multicolumn{5}{|l|}{ Seeding rate $(\mathrm{SR})^{2}$} \\
\hline 150 & $62.56 \mathrm{~A}$ & 2.28 & 89.07 & $1.610 \mathrm{~B}$ \\
\hline 300 & $35.55 \mathrm{~B}$ & 2.20 & 90.14 & $1.642 \mathrm{AB}$ \\
\hline \multirow[t]{2}{*}{450} & $25.00 \mathrm{C}$ & 2.24 & 90.50 & $1.793 \mathrm{~A}$ \\
\hline & \multicolumn{4}{|c|}{ Mean squares } \\
\hline $\mathrm{C}$ & $105.4^{\mathrm{ns}}$ & $0.65^{*}$ & $162.2^{\mathrm{ns}}$ & $343175^{*}$ \\
\hline S & $572.4^{*}$ & $0.46^{\mathrm{ns}}$ & $202.7 *$ & $1782461 *$ \\
\hline SR & $9004.1^{*}$ & $0.007^{\mathrm{ns}}$ & $13.27^{\mathrm{ns}}$ & $228932 *$ \\
\hline $\mathrm{C} * \mathrm{~S}$ & $11.93^{\mathrm{ns}}$ & $0.060^{\mathrm{ns}}$ & $330.86^{*}$ & $421004 *$ \\
\hline $\mathrm{C} * \mathrm{SR}$ & $23.37^{\text {ns }}$ & $0.024^{\mathrm{ns}}$ & $16.61^{\mathrm{ns}}$ & $360322 *$ \\
\hline $\mathrm{S} * \mathrm{SR}$ & $111.32^{\mathrm{ns}}$ & $0.045^{\mathrm{ns}}$ & $93.91^{\mathrm{ns}}$ & $57558^{\text {ns }}$ \\
\hline $\mathrm{C} * \mathrm{~S} * \mathrm{SR}$ & $50.91^{\mathrm{ns}}$ & $0.030^{\mathrm{ns}}$ & $17.96^{\mathrm{ns}}$ & $56761^{\mathrm{ns}}$ \\
\hline CV (\%) & 23.02 & 8.42 & 8.51 & 15.44 \\
\hline
\end{tabular}

${ }^{1}$ Spacing between rows $(\mathrm{m}) .{ }^{2}$ Seeding rate (one thousand viable seeds ha ${ }^{-1}$ ). ${ }^{3}$ Means followed by the same letter in a column are not significantly different from each other as determined from the Tukey test at $5 \%$ significance. ${ }^{4} \mathrm{~ns}$ : not significant and $*$ : statistically significant at $5 \%$ significance.

Emerged plant densities were 137, 257, and 392 thousand plants $\mathrm{ha}^{-1}$ in the 2013/14 growing season and 167, 311, and 474 thousand plants ha ${ }^{-1}$ in the 2014/15 season. Different rates are due to the edaphoclimatic conditions during the germinationemergence period. There was no influence of the cultivars on the emergent plant density. Different row spacing caused a mean variation of $10 \%$ in the emerged plant density.
In the 2013/14 season, there was no interaction between the experimental factors for the number of pods per plant (Table 1). Narrow rows presented the largest number, not statistically differing from the twin row. The more equidistant the plant distribution of this spacing type, probably favored branching, and higher pod production per plant.

An increased plant density decreases the participation of each plant in the final production 
(COX et al., 2010), so the number of pods per plant in the 2013/14 season was reduced with the increased seeding rate (Table 1). This result shows that the cultivars used, although presenting indeterminate growth type, early cycle, and more compact structure than older cultivars, also have high plasticity. Thus, high phenotypic plasticity in soybean cultivars can be a tool to mitigate costs or seeding problems, allowing lower seeding rates without reducing grain yield (BOARD; KAHLON, 2013; LUCA; HUNGRIA, 2014; THOMPSON et al., 2015).
The 2014/15 season showed an interaction between cultivar and row spacing, cultivar and seeding rate, and seeding rate and row spacing, for number of pods per plant (Table 2). The BMX Potência RR cultivar presented higher number of pods per plant with twin rows than with narrow rows (Table 3). The BRS 359 RR cultivar presented fewer pods per plant with narrow rows than with traditional and crossed rows (Table 3). In all arrangements, the BRS 359 RR presented lower number of pods per plant than the BMX Potência RR cultivar (Table 3 ).

Table 2. Number of pods per plant (NPP), number of grains per pod (NGP), mass of one thousand grains (g) (M1000), plant mortality rate (MORT), apparent harvest index (AHI), and grain yield $\left(\mathrm{kg} \mathrm{ha}^{-1}\right)$ (YIELD) of soybean cultivars in response to different plant spatial arrangements. Londrina-PR, 2014/15 season.

\begin{tabular}{|c|c|c|c|c|c|c|}
\hline Variation factor & NPP & NGP & M1000 & MORT & AHI & YIELD \\
\hline \multicolumn{7}{|l|}{ Cultivar (C) } \\
\hline BMX Potência RR & 45.91 & 2.46 & $120.68 \mathrm{~B}^{3}$ & 10.27 & $0.47 \mathrm{~B}$ & $2.855 \mathrm{~B}$ \\
\hline BRS 359 RR & 29.60 & 2.47 & $164.64 \mathrm{~A}$ & 10.44 & $0.52 \mathrm{~A}$ & $3.355 \mathrm{~A}$ \\
\hline \multicolumn{7}{|l|}{ Spacing $(\mathrm{S})^{1}$} \\
\hline 0.2 & 32.25 & 2.51 & 146.84 & 16.55 & 0.49 & 2.985 \\
\hline $0.2 / 0.8$ & 39.46 & 2.44 & 137.39 & 6.75 & 0.5 & 3.201 \\
\hline 0.5 & 39.79 & 2.43 & 142.60 & 7.39 & 0.49 & 3.096 \\
\hline 0.5 crossed & 39.51 & 2.49 & 143.82 & 10.73 & 0.5 & 3.138 \\
\hline \multicolumn{7}{|l|}{ Seeding rate $(\mathrm{SR})^{2}$} \\
\hline 150 & 57.66 & 2.52 & $135.75 \mathrm{~B}$ & 606 & 0.5 & 2.995 \\
\hline 300 & 33.45 & 2.44 & $144.19 \mathrm{~A}$ & 11.96 & 0.49 & 3.157 \\
\hline \multirow[t]{2}{*}{450} & 22.16 & 2.45 & $148.04 \mathrm{~A}$ & 13.04 & 0.5 & 3.163 \\
\hline & \multicolumn{6}{|c|}{ Mean squares } \\
\hline $\mathrm{C}$ & $4789.4^{*}$ & $0.004^{\mathrm{ns}}$ & $34770^{*}$ & $0.54^{\mathrm{ns}}$ & $0.05^{*}$ & $4491733^{*}$ \\
\hline $\mathrm{S}$ & $242.6^{*}$ & $0.02^{\mathrm{ns}}$ & $279.2^{\mathrm{ns}}$ & $361.8^{*}$ & $0.001^{\mathrm{ns}}$ & $148211^{\mathrm{ns}}$ \\
\hline SR & $7895.5^{*}$ & $0.04^{\mathrm{ns}}$ & $948.9 *$ & $338.1^{*}$ & $0.003^{\mathrm{ns}}$ & $216384^{\mathrm{ns}}$ \\
\hline $\mathrm{SR} * \mathrm{~S}$ & $217.90^{*}$ & $0.007^{\mathrm{ns}}$ & $133.69^{\text {ns }}$ & $1.51^{\mathrm{ns}}$ & $0.002^{\mathrm{ns}}$ & $378958^{\mathrm{ns}}$ \\
\hline $\mathrm{C} * \mathrm{SR}$ & $378.25^{*}$ & $0.041^{\mathrm{ns}}$ & $30.55^{\mathrm{ns}}$ & $3.50^{\mathrm{ns}}$ & $0.002^{\mathrm{ns}}$ & $259209^{\mathrm{ns}}$ \\
\hline $\mathrm{S} * \mathrm{SR}$ & $107.19^{*}$ & $0.019^{\mathrm{ns}}$ & $46.02^{\mathrm{ns}}$ & $4.95^{*}$ & $0.0006^{\mathrm{ns}}$ & $84223^{\text {ns }}$ \\
\hline $\mathrm{C} * \mathrm{~S} * \mathrm{SR}$ & $68.85^{\mathrm{ns}}$ & $0.006^{\mathrm{ns}}$ & $293.58^{\text {ns }}$ & $1.52^{\mathrm{ns}}$ & $0.0007^{\mathrm{ns}}$ & $138822^{\text {ns }}$ \\
\hline CV (\%) & 17.79 & 5.29 & 7.67 & 42.11 & 4.29 & 13.34 \\
\hline
\end{tabular}

${ }^{1}$ Spacing between rows $(\mathrm{m}) .{ }^{2}$ Seeding rate (one thousand viable seeds $\mathrm{ha}^{-1}$ ). ${ }^{3}$ Means followed by the same letter in a column are not significantly different from each other as determined from the Tukey test at $5 \%$ significance. ${ }^{4} \mathrm{~ns}$ : not significant and *: statistically significant at $5 \%$ significance. 
Table 3. Number of pods per soybean plant in response to interactions between cultivar and row spacing, cultivar and seeding rate, and seeding rate and row spacing. Londrina-PR, 2014/15 season.

\begin{tabular}{|c|c|c|c|}
\hline & \multicolumn{3}{|c|}{ Cultivar } \\
\hline Spacing $(\mathrm{m})$ & BMX Potência RR & & BRS 359 RR \\
\hline 0.2 & $42.46 \mathrm{Ba}^{2}$ & & $22.05 \mathrm{Bb}$ \\
\hline $0.2 / 0.8$ & $51.31 \mathrm{Aa}$ & & $27.60 \mathrm{ABb}$ \\
\hline 0.5 & $46.06 \mathrm{ABa}$ & & $33.53 \mathrm{Ab}$ \\
\hline 0.5 crossed & $43.81 \mathrm{ABa}$ & & $35.21 \mathrm{Ab}$ \\
\hline p-value & \multicolumn{3}{|c|}{0.0052} \\
\hline \multicolumn{4}{|l|}{ Seeding rate ${ }^{1}$} \\
\hline 150 & $69.92 \mathrm{Aa}$ & & $45.40 \mathrm{Ab}$ \\
\hline 300 & $41.32 \mathrm{Ba}$ & & $25.57 \mathrm{Bb}$ \\
\hline 450 & $26.49 \mathrm{Ca}$ & & $17.83 \mathrm{Cb}$ \\
\hline $\mathrm{p}$-value & \multicolumn{3}{|c|}{0.0008} \\
\hline & \multicolumn{3}{|c|}{ Seeding rate $^{1}$} \\
\hline Spacing $(\mathrm{m})$ & 150 & 300 & 450 \\
\hline 0.2 & $48.15 \mathrm{Ba}$ & $31.36 \mathrm{Ab}$ & $17.25 \mathrm{Ac}$ \\
\hline $0.2 / 0.8$ & $59.79 \mathrm{Aa}$ & $31.24 \mathrm{Ab}$ & $27.36 \mathrm{Ab}$ \\
\hline 0.5 & $64.96 \mathrm{Aa}$ & $34.36 \mathrm{Ab}$ & $20.07 \mathrm{Ac}$ \\
\hline 0.5 crossed & 57.74 Aba & $36.83 \mathrm{Ab}$ & $23.96 \mathrm{Ac}$ \\
\hline $\mathrm{p}$-value & \multicolumn{3}{|c|}{0.0439} \\
\hline CV (\%) & \multicolumn{3}{|c|}{17.79} \\
\hline
\end{tabular}

${ }^{1}$ Seeding rate (one thousand viable seeds $\mathrm{ha}^{-1}$ ). ${ }^{2}$ Means followed by the same letter (uppercase in the column and lowercase in the row) are not significantly different from each other as determined from the Tukey test.

In the same way as in 2013/14, in both cultivars, the number of pods per plant decreased as seeding rate increased, as reported by Cox and Cherney (2011). The interaction between spacing and seeding rate shows that the seeding rate decreased the number of pods per plant in all types of spacing. At a seeding rate of 150 thousand viable seeds ha-1, narrow rows resulted in fewer pods per plant, with no statistical difference from crossed rows, whereas with other seeding rates there was no difference between types of spacing (Table 3).

The number of grains per pod was not affected by plant arrangement in either growing season (Tables 1 and 2). According to Cox and Cherney (2011), the number of grains per pod is a yield component that typically is little-affected by row spacing and plant density. In the 2013/14 season, the BMX Potência RR presented a higher number of grains per pod than the BRS 359 RR (Table 1). The pod development period of the BMX Potência RR was less affected by the severe water deficit in January and February, probably because it has a longer cycle than the BRS 359 RR (Figure 1a), which resulted in a lower percentage of empty locules. It should be noted that under this low water availability condition, none of the spatial arrangements tested resulted in an environment more favorable to plant development, for increasing the number of grains per pod. In the 2014/15 season, even with better rainfall distribution (Figure 1b), there was no difference in the number of grains per pod between the cultivars (Table 2).

There was interaction between cultivar and row spacing in the 2013/14 season regarding the mass of one thousand grains. The BMX Potência RR showed no difference among the tested rows, whereas the BRS 359 RR had better results with traditional rows than with narrow and twin rows (Table 4). It is noteworthy that in this growing season none of the tested rows presented a mass of one thousand grains statistically higher than the traditional row with both cultivars. 
Table 4. Mass of one thousand grains $(\mathrm{g})$ in response to the interaction between cultivar and row spacing. LondrinaPR, 2013/14 season.

\begin{tabular}{ccc}
\hline & \multicolumn{3}{c}{ Cultivar } \\
\hline Spacing $(\mathrm{m})$ & BMX Potência RR & BRS 359 RR \\
\hline 0.2 & $86.67 \mathrm{Aa}^{1}$ & $83.54 \mathrm{Ba}$ \\
$0.2 / 0.8$ & $93.17 \mathrm{Aa}$ & $90.10 \mathrm{Ba}$ \\
0.5 & $85.13 \mathrm{Ab}$ & \\
0.5 crossed & $88.63 \mathrm{Aa}$ & $91.22 \mathrm{Aa}$ \\
p-value & & 0.0022 \\
\hline CV $(\%)$ & 8.51 \\
\hline
\end{tabular}

${ }^{1}$ Means followed by the same letter (uppercase in the column and lowercase in the row) are not significantly different from each other as determined from the Tukey test.

At the lowest seeding rate, the mass of one thousand grains was lower at the rates of 300 and 450 thousand viable seeds ha-1 (Table 2). The mass of one thousand grains was expected to be reduced with an increased seeding rate due to an increased intraspecific competition for the resources available in the environment. However, these study results agree with those observed by Ferreira et al. (2016) and Werner et al. (2017), who reported an increase in the mass of one thousand grains with an increase in the seeding rate.

Plants cultivated at a lower seeding rate show a higher percentage of grains per branch (FERREIRA et al., 2016), which have a lower demand for photoassimilates than the main stem (BALBINOT JUNIOR et al., 2015a), justifying a lower mass of one thousand grains at lower seeding rates. Tourino et al. (2002) reported that the increased mass of one thousand grains as a result of increased seeding rate occurs due to the lower number of pods per plant competing for photoassimilates, which consequently results in higher concentration of photoassimilates in these grains.

There was interaction between spacing and seeding rate for plant mortality rate (Table 2). In general, narrow rows associated with a high seeding rate, result in a high mortality rate (Table 5). According to Balbinot Junior et al. (2015b), the use of a high plant density associated with narrow rows increases intraspecific competition, resulting in higher plant mortality. Spatial arrangements using traditional, twin, and crossed rows associated with high seeding rate did not increase the mortality rate.

Table 5. Mortality rate of soybean plants (\%) in response to the interaction between row spacing and seeding rate. Londrina-PR, 2014/15 season.

\begin{tabular}{cccc}
\hline & \multicolumn{3}{c}{ Seeding rate $^{1}$} \\
\hline Spacing $(\mathrm{m})$ & 150 & 300 & 450 \\
\hline 0.2 & $3.28 \mathrm{Ab}^{2}$ & $18.63 \mathrm{Aa}$ & $27.75 \mathrm{Aa}$ \\
$0.2 / 0.8$ & $6.52 \mathrm{Aa}$ & $8.37 \mathrm{Aa}$ & $5.38 \mathrm{Ba}$ \\
0.5 & $5.2 \mathrm{Aa}$ & $9.34 \mathrm{Aa}$ & $7.63 \mathrm{Ba}$ \\
0.5 crossed & $9.27 \mathrm{Aa}$ & $11.49 \mathrm{Aa}$ & $11.42 \mathrm{Ba}$ \\
\hline -value & & 0.007 & \\
\hline $\mathrm{CV}(\%)$ & & 42.11 & \\
\hline
\end{tabular}

${ }^{1}$ Seeding rate (one thousand viable seeds $\mathrm{ha}^{-1}$ ). ${ }^{2}$ Means followed by the same letter (uppercase in the column and lowercase in the row) are not significantly different from each other as determined from the Tukey test. 
The BMX Potência RR and BRS 359 RR cultivars presented an AHI of 0.47 and 0.52, respectively (Table 2). According to Hay (1995), AHI values range between 0.4 and 0.6 in most grain crops. These values are influenced by genetic constitution and production environment. However, in this present study, AHI was influenced only by genotype, not varying with plant arrangement in the two seasons with restrictive meteorological conditions. This result demonstrates the high phenotypic plasticity of the cultivars used, as the allocation of phytomass between reproductive and vegetative structures remained constant even with the use of discrepant spatial arrangements. A positive factor related to this characteristic is that even in stand failure situations or when there is a high plant density, the percentage of phytomass allocated in the grains remains constant. On the other hand, a related negative practical aspect is the impossibility of changing plant arrangements with the objective of increasing the allocation of phytomass in the grains, by decreasing it in vegetative structures.

In the 2013/14 season, yield was influenced by interactions between cultivar and row spacing, and cultivar and seeding rate (Table 1). The BMX Potência RR cultivar showed a lower yield in twin rows than in other types of spacings (Table 6). In this treatment, the total canopy closure did not occur due to the wide distance between twin rows $(0.8 \mathrm{~m})$, probably due to the low availability of water in this growing season (Figure 1a).

Table 6. Soybean yield $\left(\mathrm{kg} \mathrm{ha}^{-1}\right)$ in response to the interaction between cultivars and row spacing, and cultivars and seeding rate. Londrina-PR, 2013/14 season.

\begin{tabular}{|c|c|c|}
\hline & \multicolumn{2}{|c|}{ Cultivar } \\
\hline Spacing $(\mathrm{m})$ & BMX Potência RR & BRS 359 RR \\
\hline 0.2 & $1.713 \mathrm{Aa}^{2}$ & $1.567 \mathrm{BCa}$ \\
\hline $0.2 / 0.8$ & $1.047 \mathrm{Bb}$ & $1.465 \mathrm{Ca}$ \\
\hline 0.5 & $1.770 \mathrm{Ab}$ & $2.156 \mathrm{Aa}$ \\
\hline 0.5 crossed & $1.922 \mathrm{Aa}$ & $1.815 \mathrm{Ba}$ \\
\hline $\mathrm{p}$-value & & \\
\hline \multicolumn{3}{|l|}{ Seeding rate $^{1}$} \\
\hline 150 & $1.664 \mathrm{Aa}$ & $1.556 \mathrm{Ba}$ \\
\hline 300 & $1.573 \mathrm{Aa}$ & $1.712 \mathrm{Ba}$ \\
\hline 450 & $1.602 \mathrm{Ab}$ & $1.984 \mathrm{Aa}$ \\
\hline p-value & & \\
\hline CV (\%) & & \\
\hline
\end{tabular}

${ }^{1}$ Seeding rate (one thousand viable seeds $\mathrm{ha}^{-1}$ ). ${ }^{2}$ Means followed by the same letter (uppercase in the column and lowercase in the row) are not significantly different from each other as determined from the Tukey test.

The BRS 359 RR showed the highest yield with traditional rows and the lowest yield with twin rows, although it showed no statistical difference compared to narrow rows. The highest yield obtained with traditional rows is related to the largest mass of one thousand grains obtained in this treatment (Table 5).

Procópio etal.(2014)reported noyield differences in soybeans cultivated in twin rows spaced 0.20/0.40 $\mathrm{m}$ and $0.20 / 0.60 \mathrm{~m}$ when compared to $0.40 \mathrm{~m}$ spacing. However, in the present study, there was a reduction in grain yield in twin row cultivation in the 2013/14 season. The area not covered by the canopy, with twin row spacing, was determinant for the maximum use of the environmental resources in this season of unfavorable weather conditions, besides favoring the evaporation of the soil water, reducing grain yield with both cultivars. 
According to Suhre et al. (2014), higher soybean yields are obtained when canopy closure occurs before pod development-R3 stage-and a reduced grain yield may occur if there is no closure before the beginning of grain filling, i.e., stage R5. The major disadvantage of twin rows is the possibility of increased weed infestation and loss of the solar radiation that is not intercepted by the canopy due to delayed closure, as discussed by Procópio et al. (2014).

In general, reduced spacing negatively impacted grain yield of BRS 359 RR in the 2013/14 season. Reduced spacing between rows in a same plant density results in better plant distribution in the area. In this way, intraspecific competition is reduced due to greater equidistance between plants, and greater water efficiency (ZHOU et al., 2015). However, De Bruin and Pedersen (2008) reported that the soybean response to spacing reduction varies according to crops, localities, cultivars, sowing time, and soil management.

Crossed row spacing did not result in increased yields when compared to traditional rows with either cultivar. This spacing is less efficient due to its higher operating cost and lower net revenue (SILVA et al., 2015). Crossed rows reduce the operational seeding capacity by half, besides doubling the use of sowing machines, which increases soil compaction. They also result in greater soil movement, which may favor erosion and the growth of weeds in the sowing lines (BALBINOT JUNIOR et al., 2016).

The BRS 359 RR yield was superior to the BMX Potência RR yield at the highest seeding rate, with no differences at other rates. The comparison of seeding rates for each cultivar showed that seeding rate did not change grain yield with the BMX Potência RR cultivar. However, with BRS 359 $\mathrm{RR}$, the highest grain yield was obtained with 450 thousand viable seeds $\mathrm{ha}^{-1}$. This seeding rate is $70 \%$ higher than the maximum rate recommended for this cultivar in the studied region.
As for the 2014/15 harvest, there was no influence of spatial arrangement on grain yield, but the cultivar had an effect. Comparing the means of all arrangements, the BRS 359 RR produced 500 $\mathrm{kg} \mathrm{ha}^{-1}$ more than the BMX Potência RR (Table 2 ). The phenotypic soybean plasticity in response to changes in plant spatial arrangement is greater when environmental conditions are favorable during the period of crop development, increasing the productive potential of each plant (DE BRUIN; PEDERSEN, 2008). Therefore, the most favorable weather conditions in the 2014/15 season, especially in the most critical period - grain filling - was determinant to maintain the yield in the different spatial arrangements tested.

It should be noted that the tested alternative spacing did not statistically outperform the yield obtained with traditional spacing in both seasons. In addition, the increased yield obtained with the highest seeding rate with the BRS 359 RR in 2013/14 was not repeated in the second season (Table 2). Likewise, Moreira et al. (2015) had no yield increases due to spacing modification $(0.3$ to $0.5 \mathrm{~m})$ and seeding rate (220 to 670 thousand plants ha ${ }^{-1}$ ) under similar edaphoclimatic conditions compared to the present study. According to Balbinot Junior et al. (2015b) and Corassa et al. (2018), reduced spacing or increased seeding rates generally only increase soybean yield in environments that restrict vegetative plant growth. These facts, associated with lack of sowing machines appropriated for twin rows and narrow spacing, and the difficult sowing operation for crossed rows, indicate the greater efficiency of the $0.5 \mathrm{~m}$ traditional spacing already adopted by farmers.

\section{Conclusions}

Narrow, twin, and crossed rows do not favor productive performance when compared to traditional spacing for both cultivars. 
The BMX Potência RR and BRS 359 RR cultivars have high phenotypic plasticity, allowing row spacing and seeding rate changes without significant differences in yield.

Narrow rows increase plant mortality when associated with high seeding rate.

Number of grains per pod and harvest index are not influenced by plant spatial arrangement.

\section{Referências}

ALLEN, R. G.; PEREIRA, L. S.; RAES, D.; SMITH, M. Crop evapotranspiration: guidelines for computing crop water requirements FAO irrigation and drainage paper 56. Roma: Food and Agriculture Organization of United Nations, 1998. 300 p.

BALBINOT JUNIOR, A. A.; PROCOPIO, S. O.; COSTA, J. M.; KOSINSKI, C. L.; PANISON, F.; DEBIASI, H.; FRANCHINI, J. C. Espaçamento reduzido e plantio cruzado associados a diferentes densidades de plantas de soja. Semina: Ciências Agrárias, Londrina, v. 36, n. 5, p. $2977-2986,2015$ b. DOI: $10.5433 / 1679-0359.2015 \mathrm{v} 3$ 6n5p2977

BALBINOT JUNIOR, A. A.; PROCÓPIO, S. O.; DEBIASI, H.; FRANCHINI, J. C.; PANISON, F. Semeadura cruzada em cultivares de soja com tipo de crescimento determinado. Semina: Ciências Agrárias, Londrina, v. 36, n. 3, p. 1215-1226, 2015a. DOI: 10.5433/1679-0359.2015v36n3p1215

BALBINOT JUNIOR, A. A.; PROCOPIO, S. de O.; NEUMAIER, N.; FERREIRA, A. S.; WERNER, F.; DEBIASI, H.; FRANCHINI, J. C. Semeadura cruzada, espaçamento entre fileiras, e densidade de semeadura influenciando o crescimento e a produtividade de duas cultivares de soja. Revista de Ciências Agroveterinárias, Lages, v. 15, n. 2, p. 83-93, 2016.

BOARD, J. E.; KAHLON, C. S. Morphological responses to low plant population differ between soybean genotypes. Crop Science, Madison, v. 53, n. 3, p. 11091119, 2013.

BRUNS, H. A. Comparisons of single-row and twin row soybean production in the Mid-South. Agronomy Journal, Madison, v. 103, n. 3, p. 702-708, 2011a. DOI: 10.2134/agronj2010.0475

BRUNS, H. A. Planting date, rate and twin-row vs. single-row soybean in the Mid-South. Agronomy Journal, Madison, v. 103, n. 5, p. 1308-1313, 2011 b. DOI: 10.2134/agronj2011.0076
CORASSA, G. M.; AMADO, T. J. C.; STRIEDER, M. L.; SCHWALBERT, R.; PIRES, J. L. F.; CARTER, P. R.; CIAMPITTI, I. A. Optimum soybean seeding rates by yield environment in southern Brazil. Agronomy Journal, Madison, v. 110, n. 6, p. 1-9, 2018.

COX, W. J.; CHERNEY, J. H. Growth and yield responses of soybean to row spacing and seeding rate. Agronomy Journal, Madison, v. 103, n. 1, p. 123-128, 2011. DOI: 10.2134/agronj2010.0316

COX, W. J.; CHERNEY, J. H.; SHIELDS, E. Soybeans compensate at low seeding rate but not at high thinning rates. Agronomy Journal, Madison, v. 102, n. 4, p. 12381243, 2010. DOI: 10.2134/agronj2010.0047

DE BRUIN, J. L.; PEDERSEN, P. Effect of row spacing and seeding rate on soybean yield. Agronomy Journal, Madison, v. 100, n. 3, p. 704-710, 2008. DOI: $10.2134 /$ agronj2007.0106

LUCA, M. J.; HUNGRIA, M. Plant densities and modulation of symbiotic nitrogen fixation in soybean. Scientia Agricola, Piracicaba, v. 71, n. 3, p. 181-187, 2014. DOI: $10.1590 / \mathrm{S} 0103-90162014000300002$

FERREIRA, A. S.; BALBINOT JUNIOR, A. A.; WERNER, F.; ZUCARELI, C.; FRANCHINI, J. C.; DEBIASI, H. Plant density and mineral nitrogen fertilization influencing yield, yield components and concentration of oil and protein in soybean grains. Bragantia, Campinas, v. 75, n. 3, p. 362-370, 2016. DOI: $10.1590 / 1678-4499.479$

HANNA, S. O.; CONLEY, S. P.; SHANER, G. E.; SANTINI, J. B. Fungicide application timing and row spacing effect on soybean canopy penetration and grain yield. Agronomy Journal, Madison, v. 100, n. 5, p. 14881492, 2008. DOI: 10.2134/agronj2007.0135

HAY, R. K. M. Harvest index: a review of its use in plant breeding and crop physiology. Annals of Applied Biology, London, v. 126, n. 1, p. 197-216, 1995. DOI: 10.1111/j.1744-7348.1995.tb05015.x

KOESTER, R. P.; SKONECZKA, J. A.; CARY, T. R.; DIERS, B. W.; AINSWORTHY, E. A. Historical gains in soybean (Glycine max Merr.) seed yield are driven by linear increases in light interception, energy conversion, and partitioning efficiencies. Journal of Experimental Botany, Oxford, v. 65 , n. 12, p. 3311-3321, 2014. DOI: $10.1093 / \mathrm{jxb} /$ eru187

MOREIRA, A.; MORAES, L. A. C.; SCHROTH, G.; MANDARINO, J. M. G. Effect of nitrogen, row spacing, and plant density on yield, yield components, and plant physiology in soybean-wheat intercropping. Agronomy Journal, Madison, v. 107, n. 6, p. 2162-2170, 2015. DOI: 10.2134/agronj15.0121 
PROCÓPIO, S. O.; BALBINOT JUNIOR, A. A.; DEBIASI, H.; FRANCHINI, J. C.; PANISON, F. Semeadura em fileira dupla e espaçamento reduzido na cultura da soja.Agro@mbiente On-line, Boa Vista, v. 8, n. 2 , p. 212-221, 2014. DOI: 10.18227/1982-8470ragro. v8i2.1469

SILVA, P. R. A.; TAVARES, L. A. F.; SOUSA, S. F. G.; CORREIA, T. P. S.; RIQUETTI, N. B. Rentabilidade na semeadura cruzada da cultura da soja. Revista Brasileira de Engenharia Agrícola e Ambiental, Campina Grande, v. 19, n. 3, p. 293-297, 2015.

SOUZA, C. A.; GAVA, F.; CASA, R. T.; BOLZAN, J. M.; KUHNEM JUNIOR, P. R. Relação entre densidade de plantas e genótipos de soja Roundup Ready TM. Planta Daninha, Viçosa, MG, v. 28, n. 4, p. 887-896, 2010.

SUHRE, J. J.; WEIDENBENNER, N. H.; ROWNTREE, S. C.; WILSON, E. W.; NAEVE, S. L.; CONLEY, S. P.; CASTEEL, S. N.; DIERS, B. W.; ESKER, P. D.; SPECHT, J. E.; DAVIS, V. M. Soybean yield partitioning changes revealed by genetic gain and seeding rate interactions. Agronomy Journal, Madison, v. 106, n. 5, p. 1631-1642, 2014. DOI: 10.2134/agronj14.0003

THOMPSON, N. M.; LARSON, J. A.; LAMBERT, D. M.; ROBERTS, R. K.; MENGISTU, A.; BELLALOUI, N.; WALKER, E. R. Mid-South soybean yield and net return as affected by plant population and row spacing. Agronomy Journal, Madison, v. 107, n. 3, p. 979-989, 2015. DOI: 10.2134 /agronj14.0453
TOURINO, M. C. C.; REZENDE, P. M.; SALVADOR, N. Espaçamento, densidade e uniformidade de semeadura na produtividade e características agronômicas da soja. Pesquisa Agropecuária Brasileira, Brasília, v. 37, n. 8, p. 1071-1077, 2002.

WERNER, F.; BALBINOT JUNIOR, A. A.; FERREIRA, A. S.; AGUIAR E SILVA, M. A.; DEBIASI, H.; FRANCHINI, J. C. Soybean growth affected by seeding rate and mineral nitrogen. Revista Brasileira de Engenharia Agrícola e Ambiental, Campina Grande, v. 20, n. 8, p. 734-738, 2016. DOI: 10.1590/1807-1929/ agriambi.v20n8p 734-738

WERNER, F.; BALBINOT JUNIOR, A. A.; FERREIRA, A. S.; AGUIAR E SILVA, M. A.; MANDARINO, J. M. G.; ZUCARELI, C. Size, chlorophyll retention and protein and oil contents of grains from soybean plants grown in different spatial arrangements. Semina: Ciências Agrárias, Londrina, v. 38, n. 1, p. 85-96, 2017. DOI: $10.5433 / 1679-0359.2017 \mathrm{v} 38 \mathrm{n} 1 \mathrm{p} 85$

ZHOU, X. B.; CHEN, Y. H.; OUYANG, Z. Spacing between rows: effects on water-use efficiency of doublecropped wheat and soybean. Journal of Agricultural Science, Cambridge, v. 153, n. 1, p. 90-101, 2015. DOI: $10.1017 / \mathrm{S} 0021859613000890$ 